\title{
THE INHERITANCE OF THE DUFFY BLOOD GROUPS : AN ANALYSIS OF 110 ENGLISH FAMILIES
}

\author{
R. R. RACE and RUTH SANGER \\ Medical Research Council Blood Group Research Unit, Lister Institute of \\ Preventive Medicine, London, S.W. I \\ Received 7.ix.5r
}

The Duffy blood group system was discovered by Cutbush, Mollison and Parkin in 1950. The anti-Duffy serum, anti-Fya, divides human beings into two phenotypes, those whose red cells are sensitised, $F y(a+)$, and those whose red cells are not, $F y(a-)$.

Cutbush and Mollison (1950) tested 27 families with 49 children and demonstrated that the antigen $F y^{a}$ is inherited by means of a gene which expresses itself in single as well as in double dose. This was confirmed by Race, Holt and Thompson (I95I) who tested $5^{8}$ families with 148 children.

Anti- $F y^{a}$ has not yet been shown to make a dosage distinction between bloods representing the genotype $F^{a} F^{a} y^{a}$ and those representing the genotype $F y^{a} F^{b}$; nor has an antiserum anti- $F y^{b}$ yet been identified. $F y^{a}$ is therefore in the phase, usually fleeting for blood group antigens, in which it may properly be called a dominant Mendelian character.*

The present paper reports the results of testing a further $5^{2}$ families for the Duffy groups. These families are shown in table i, together with the $5^{8}$ families of Race, Holt and Thompson; the total of I Io families with 274 children are analysed below.

Ascertainment.-The families of table I were quite unselected as far as blood groups are concerned. There was some selection for families with two or more children.

Treins. - When a pair of twins was not shown to be dizygous by sex or by any of the blood groups it has been scored as one child.

Other blood group systems. - The families have also been tested for the $A_{1} A_{2} B O, M \mathcal{N S}, P, R h$, Lutheran, Kell and Lewis groups. About half of them have also been tested for the Kidd groups.

Linkage.--In the previous paper (Race et al., I95I) it was reported. that no evidence could be found for linkage between the Duffy genes and the genes for other blood groups, or for phenyl thio-carbamide testing; nor was there any evidence for partial sex linkage of the Duffy genes. The present addition of 52 families supports this independent segregation of the Duffy genes. Linkage calculations. are not given for they form part of a paper on linkage and the blood groups at present in preparation (Holt, Thompson, Sanger and Race).

* Since the writing of this paper both an anti-Fy ${ }^{a}$ showing a dosage effect and an example of anti-Fy have been found. 


\section{GENE FREQUENCIES}

The gene frequencies used in the calculations to follow are derived from the frequency of the Duffy phenotypes of unrelated English

TABLE I

The Duffy blood groups of 110 English families with 274 children

\begin{tabular}{|c|c|c|c|c|c|}
\hline \multirow{2}{*}{$\begin{array}{l}\text { Group } \\
\text { number }\end{array}$} & \multirow{2}{*}{ Father } & \multirow{2}{*}{ Mother } & \multirow{2}{*}{$\begin{array}{l}\text { Number of } \\
\text { families }\end{array}$} & \multicolumn{2}{|c|}{ Children } \\
\hline & & & & $F y(a+)$ & $F y(a-)$ \\
\hline I & $F y(a+)$ & $F y(a+)$ & $\begin{array}{r}8 \\
18 \\
5 \\
1\end{array}$ & $\begin{array}{l}1 \\
2 \\
3 \\
4\end{array}$ & $\begin{array}{l}\overline{-} \\
\overline{-}\end{array}$ \\
\hline 2 & $F y(a+)$ & $F y(a+)$ & $\begin{array}{l}5 \\
3 \\
1 \\
1 \\
1 \\
\text { I }\end{array}$ & $\begin{array}{l}1 \\
1 \\
2 \\
3 \\
3 \\
6\end{array}$ & $\begin{array}{l}1 \\
2 \\
1 \\
1 \\
2 \\
2\end{array}$ \\
\hline 3 & $\begin{array}{l}F y(a+) \\
F y(a-)\end{array}$ & $\begin{array}{l}F y(a-) \\
F y(a+)\end{array}$ & $\begin{array}{l}1 \\
3 \\
3 \\
2 \\
3 \\
4 \\
1 \\
1\end{array}$ & $\begin{array}{l}1 \\
2 \\
3 \\
6 \\
1 \\
2 \\
4 \\
5\end{array}$ & $\begin{array}{l}= \\
= \\
= \\
= \\
= \\
=\end{array}$ \\
\hline 4 & $\begin{array}{l}F y(a+) \\
F y(a-)\end{array}$ & $F y(a-)$ & $\begin{array}{l}1 \\
4 \\
4 \\
2 \\
1 \\
1 \\
3 \\
3 \\
5 \\
1 \\
3 \\
4 \\
2 \\
1\end{array}$ & $\begin{array}{l}- \\
\overline{1} \\
1 \\
2 \\
3 \\
\overline{-} \\
\overline{1} \\
\overline{1} \\
1 \\
2 \\
1 \\
2\end{array}$ & $\begin{array}{l}\mathrm{I} \\
2 \\
1 \\
2 \\
2 \\
2 \\
1 \\
2 \\
1 \\
3 \\
2 \\
1 \\
3 \\
3\end{array}$ \\
\hline 5 & $F y(a-)$ & $F y(a-)$ & $\begin{array}{l}6 \\
5 \\
1 \\
1\end{array}$ & $\begin{array}{l}\overline{-} \\
\bar{z}\end{array}$ & $\begin{array}{l}2 \\
3 \\
4 \\
5\end{array}$ \\
\hline
\end{tabular}

people (table 2). The item "present series" represents tests done in this Unit on unrelated, unselected persons since the previous publication.

Assuming that the phenotype $F y(a-)$ represents the genotype $F y^{b} F^{b}$ then the gene frequencies may be derived in the following way :

the frequency of the gene $F y^{b}=\sqrt{0.340 \mathrm{I}}=0.5^{8} 3^{2}$ and the frequency of the gene $F y^{a}=\mathrm{x}-0.5832=0.4168$ 
TABLE 2

The frequency of the Duffy phenotypes in England

\begin{tabular}{|c|c|c|c|}
\hline & Number tested & $F y(a+)$ & $F y(a-)$ \\
\hline $\begin{array}{l}\text { Cutbush and Mollison (1950) } \\
\text { Race, Holt and Thompson (1951) } \\
\text { Present series. }\end{array}$ & $\begin{array}{l}205 \\
255 \\
325\end{array}$ & $\begin{array}{ll}133 & 64 \cdot 88 \% \\
167 & 65.49 \% \\
218 & 67.08 \%\end{array}$ & $\begin{array}{rl}72 & 35 \cdot 12 \% \\
88 & 34 \cdot 51 \% \\
107 & 32 \cdot 92 \%\end{array}$ \\
\hline Total & 785 & $518 \quad 65.99 \%$ & $26734.01 \%$ \\
\hline
\end{tabular}

The genotype frequencies are therefore :-

$$
\begin{array}{llr}
F^{a}{ }^{a} y^{a} & 0.4168^{2} & =0.1737 \\
F^{a} F y^{b} & 0.4168 \times 0.5832 \times 2 & =0.4862 \\
F^{b} F^{b} & 0.5832^{2} & =0.340 \mathrm{I}
\end{array}
$$

These frequencies have been used to analyse the family material in two ways.

\section{METHOD 1}

Table 3 shows the expected incidence of the various matings and the relative frequency of $F y(a+)$ and $F y(a-)$ children of these matings. These expectations are applied in table 4 to the I Io families and their 274 children. It will be seen that there is good agreement between the calculated distribution, and that actually found.

Professor Fisher has pointed out certain objections to this method which has almost become the standard way of verifying unifactorial inheritance. The mating $F y(a+) \times F y(a+)$ is genotypically of three kinds, and the mating $F y(a+) \times F y(a-)$ of two kinds. Children from say the phenotype mating $F y(a+) \times F y(a-)$ are not independent samples from a homogeneous population, with an expectation of o.63i $6 F y(a+)$ to $0.3684 F y(a-)$, and should not be treated as independent in calculating goodness of fit. That this method does in fact usually give a very good fit is probably due to the shortage of large families in the data.

\section{METHOD 2 (a)}

In I939 Professor Fisher suggested that account should be taken separately of the totals yielded by the group of families containing recessive children, and of the individual sizes of families containing none. This method was applied to the $A_{1} A_{2} B O$ groups by Taylor and Prior (I939) and by Race, Ikin, Taylor and Prior (1942). Owing to an unfortunate lapse of memory the method was not referred to in Blood Groups in Man (Race and Sanger, I950).

Two separate comparisons with expectation are made. In $(a)$, we compare the number of families observed to contain no recessive children, irrespective of size, with the number expected, taking account 
of the estimated gene frequency and of the sizes of all families observed. In $(b)$, we compare the numbers of recessive children observed in

TABLE 3

The expected distribution of the Duffy group's in English parents and offspring

\begin{tabular}{|c|c|c|c|c|}
\hline \multicolumn{5}{|c|}{ Genotypes } \\
\hline \multicolumn{2}{|c|}{ Matings } & \multicolumn{3}{|c|}{ Children } \\
\hline Type & Frequency & $F y^{a} F y^{a}$ & $F y^{a} F y^{b}$ & $F y^{b} F y^{b}$ \\
\hline \multirow[t]{2}{*}{$\begin{array}{l}F y^{a} F y^{a} \times F y^{a} F y^{a} \\
F y^{a} F y^{a} \times F y^{a} F y^{b} \\
F y^{a} F y^{b} \times F y^{a} F y^{b} \\
F y^{a} F y^{a} \times F y^{b} F y^{b} \\
F y^{a} F y^{b} \times F y^{b} F y^{b} \\
F y^{b} F y^{b} \times F y^{b} F y^{b}\end{array}$} & $\begin{array}{l}0.0302 \\
0.1689 \\
0.2364 \\
0.1181 \\
0.3307 \\
0.1157\end{array}$ & \multirow[t]{2}{*}{$\begin{array}{c}0.0302 \\
0 \cdot 08445 \\
0 \cdot 0591 \\
\cdots \\
\cdots \\
\cdots\end{array}$} & \multirow[t]{2}{*}{$\begin{array}{l}\quad \ldots \\
0.08445 \\
0.1182 \\
0 \cdot 1181 \\
0-16535 \\
\quad \cdots\end{array}$} & \multirow[t]{2}{*}{$\begin{array}{c}\cdots \\
\cdots \\
0.059^{1} \\
\ldots \\
0 \cdot 16535 \\
0 \cdot 1157\end{array}$} \\
\hline & I-OOOO & & & \\
\hline \multicolumn{5}{|c|}{ Phenotypes } \\
\hline \multicolumn{2}{|c|}{ Matings } & \multicolumn{3}{|c|}{ Children } \\
\hline Type & Frequency & $F y(a+)$ & & $F_{y}(a-)$ \\
\hline \multirow[t]{2}{*}{$\begin{array}{l}F y(a+) \times F y(a+) \\
F y(a+) \times F y(a-) \\
F y(a-) \times F y(a-)\end{array}$} & $\begin{array}{l}0.4355 \\
0.4488 \\
0.1157\end{array}$ & \multirow[t]{2}{*}{$\begin{array}{c}0.8643 \\
0.6316 \\
\ldots\end{array}$} & & \multirow[t]{2}{*}{$\begin{array}{l}0.1357 \\
0.3684 \\
I \cdot 0000\end{array}$} \\
\hline & I $\cdot 0000$ & & & \\
\hline
\end{tabular}

TABLE 4

The Duffy groups of $r$ ro English families with 274 children analysed by method $r$

\begin{tabular}{|c|c|c|c|c|c|c|c|}
\hline \multicolumn{3}{|c|}{ Matings } & \multicolumn{5}{|c|}{ Children } \\
\hline \multirow{2}{*}{ Type } & \multicolumn{2}{|c|}{ Number } & \multirow{2}{*}{$\begin{array}{c}\text { Total } \\
\text { number }\end{array}$} & \multicolumn{2}{|c|}{$F_{y}(a+)$} & \multicolumn{2}{|c|}{$F y(a-)$} \\
\hline & Observed & Expected & & Observed & Expected & Observed & Expected \\
\hline \multirow[t]{2}{*}{$\begin{array}{l}F y(a+) \times F y(a+) \\
F y(a+) \times F y(a-) \\
F y(a-) \times F y(a-)\end{array}$} & $\begin{array}{l}44 \\
53 \\
\text { I } 3\end{array}$ & $\begin{array}{l}47 \cdot 9 \\
49 \cdot 4 \\
12 \cdot 7\end{array}$ & $\begin{array}{r}102 \\
\times 36 \\
36\end{array}$ & \multirow[t]{2}{*}{$\begin{array}{r}85 \\
79 \\
0\end{array}$} & \multirow[t]{2}{*}{$\begin{array}{r}88 \cdot 2 \\
85 \cdot 9 \\
0 \cdot 0\end{array}$} & \multirow[t]{2}{*}{$\begin{array}{l}\text { I } 7 \\
57 \\
3^{6}\end{array}$} & \multirow[t]{2}{*}{$\begin{array}{l}13 \cdot 8 \\
50 \cdot 1 \\
36 \cdot 0\end{array}$} \\
\hline & IIO & $110 \cdot 0$ & 274 & & & & \\
\hline
\end{tabular}

those families which contain any, with the numbers expected on Mendelian theory, when allowance has been made for the fact that 
at this stage, each of these families is known to contain at least one recessive child.

The formulæ given by Taylor and Prior (1939) for the matings $B \times O$ and $B \times B$ can be directly applied to matings $F y(a+) \times F y(a-)$ and $F y(a+) \times F y(a+)$. These formulæ are also applicable to family studies of the $P$, Lutheran and Kidd blood groups where

$a$ represents the gene frequency of $F y^{a}$ (or $P, L u^{a}$ or $7 k^{a}$ ) and $b$ represents the gene frequency of $F y^{b}$ (or $p, L u^{b}$ or $7 k^{b}$ )

The explanation given below is almost a direct transcription from Taylor and Prior's lucid account of the method, with the necessary change of symbols.

$$
\text { Mating } \mathrm{Fy}(\mathrm{a}+) \times \mathrm{Fy}(\mathrm{a}-)
$$

The $F y(a+)$ parent can be one of two genotypes, $F y^{a} F y^{a}$, the frequency of which is $a^{2}$, or $F y^{a} F y^{b}$ with the frequency of $2 a b$. The frequency of the phenotype $F y(a+)$ in the population is therefore $a^{2}+2 a b$; hence the probability of an $F y(a+)$ person being $F y^{a} F y^{a}$ is $\frac{a^{2}}{a^{2}+2 a b}$ or $\frac{a}{a+2 b}$, and of being $F y^{a} F y^{b}$ is $\mathrm{I}-\frac{a}{a+2 b}$. From the mating $F y^{a} F y^{a} \times F y^{b} F y^{b}$ all children will be $F y(a+)$, from the mating $F y^{a} F y^{b} \times F y^{b} F y^{b}$ some children may be $F y(a-)$. The probability of a child of the mating $F y^{a} F y^{b} \times F y^{b} F y^{b}$ being of the phenotype $F y(a+)$ is $\frac{1}{2}$, of two children being both $F y(a+)$ is $\left(\frac{1}{2}\right)^{2}$ and of $n$ children all $F y(a+)$ is $\left(\frac{1}{2}\right)^{n}$. The occurrence of an $F y(a-)$ child is at present the only means of knowing that the $F y(a+)$ parent is heterozygous, hence in the mating $F y(a+) \times F y(a-)$ the families are divided into two groups, those with all children $F y(a+)$, and those with some children $F y(a-)$.

\section{All children $\mathrm{Fy}(\mathrm{a}+)$}

Families of $I$ child.-Probability of this child being $F y(a+)=$ probability of the $F y\left(a+\right.$ ) parent being $F y^{a} F y^{a}+\frac{1}{2} \times$ (probability of the $F y(a+)$ parent being $\left.F y^{a} F y^{b}\right)=\frac{a}{a+2 b}+\frac{1}{2}\left(1-\frac{a}{a+2 b}\right)$

Therefore the expected number of families with one child, this child being $F y(a+)$

$$
=\left[\begin{array}{l}
\text { observed number of } F y(a+) \times F y(a-) \\
\text { families with one child. }
\end{array}\right] \times\left[\frac{a}{a+2 b}+\frac{1}{2}\left(\mathrm{I}-\frac{a}{a+2 b}\right)\right]
$$

Since $a=$ the frequency of the gene $F y^{a}=0.4168$, and $b=$ the frequency of the gene $F y^{b}=0.5832$ and the total number of 1 child families of the mating type $F y(a+) \times F y(a-)$ is 8 , then the expected number of such families with I child, this child being $F y(a+)$ is $8 \times 0.6316$ or $5.0528 ; 4$ were observed. 
Families of $\mathrm{n}$ children.-Probability of all $n$ children being

$$
F y(a+)=\frac{a}{a+2 b}+\left(\frac{1}{2}\right)^{n}\left(\mathrm{I}-\frac{a}{a+2 b}\right)
$$

As above, to get the expected number of such families this figure must be multiplied by the observed number of families of $n$ children with parents $F y(a+) \times F y(a-)$.

TABLE 5

Analysis of families of the mating type $\mathrm{Fy}(\mathrm{a}+) \times \mathrm{Fy}(\mathrm{a}-)$

\begin{tabular}{|c|c|c|c|}
\hline \multirow{3}{*}{ Family size } & \multirow{3}{*}{ Total families } & \multicolumn{2}{|c|}{$\begin{array}{c}\text { Number of families having only } \\
F y(a+) \text { children }\end{array}$} \\
\cline { 3 - 4 } & & Expected & Observed \\
& & $5 \cdot 0.5$ & \\
& & $10 \cdot 29$ & 4 \\
2 & 23 & $4 \cdot 62$ & 3 \\
3 & 13 & 1.24 & 1 \\
4 & 4 & $0 \cdot 86$ & 1 \\
5 & 3 & $0 \cdot 55$ & 2 \\
\hline 6 & 53 & $22 \cdot 6 I$ & 18 \\
\hline
\end{tabular}

Applying these formulx to the matings $F y(a+) \times F y(a-)$ shown in table $\mathrm{r}$, the expectations for the number of families in which all children are $F y(a+)$ are as shown in table 5 .

\section{Some children Fy $(\mathrm{a}-)$}

The expected number of families with $F y(a-)$ children is obtained by subtracting the expected number of families whose children are all $F y(a+)$ from the total number of observed families of the type $F y(a+) \times F y(a-)$. Applying this to the present investigation we find that the expected number of such families is $53-22 \cdot 61$ or 30.39 , while 35 were observed.

$$
\text { Mating } \mathrm{Fy}(\mathrm{a}+) \times \mathrm{Fy}(\mathrm{a}+)
$$

In this mating also the parents can be of two genotypes $F^{a} F^{a}$ or $F^{a} F^{b}{ }^{b}$ and the families are again divided into two groups, those with all children $F y(a+)$, and those with some children $F y(a-)$.

Probability of one parent being $F y^{a} F y^{b}=\frac{2 b}{a+2 b}$.

Probability of both parents being $F y^{a} F y^{b}=\left(\frac{2 b}{a+2 b}\right)^{2}$.

Thus the probability of at least one parent being

$$
F y^{a} F y^{a}=\mathrm{I}-\left(\frac{2 b}{a+2 b}\right)^{2} .
$$




\section{All children Fy $(\mathrm{a}+)$}

Families of $I$ child.-Probability of this child being $F y(a+)=$ the probability of at least one parent being $F y^{a} F y^{a}+\frac{3}{4} \times$ (the probability of both parents being $\left.F y^{a} F y^{b}\right)=\mathrm{I}-\left(\frac{2 b}{a+2 b}\right)^{2}+\frac{3}{4}\left(\frac{2 b}{a+2 b}\right)^{2}$

Therefore the expected number of families with I child, this child being Fy $(a+)$

$=\left[\begin{array}{l}\text { observed number of } F y(a+) \times F y(a+) \\ \text { families with } 1 \text { child. }\end{array}\right] \times\left[1-\left(\frac{2 b}{a+2 b}\right)^{2}+\frac{3}{4}\left(\frac{2 b}{a+2 b}\right)^{2}\right]$

Families of $\mathrm{n}$ children.-Probability of all children being

$$
F y(a+)=\mathrm{x}-\left(\frac{2 b}{a+2 b}\right)^{2}+\left(\frac{3}{4}\right)^{n}\left(\frac{2 b}{a+2 b}\right)^{2}
$$

Applying these formulæ to the matings $F y(a+) \times F y(a+)$ shown in table I the expectations for the number of families in which all children are $F y(a+)$ are as given in table 6.

TABLE 6

Analysis of families of the mating type $\mathrm{Fy}(\mathrm{a}+) \times \mathrm{Fy}(\mathrm{a}+)$

\begin{tabular}{|c|c|c|c|}
\hline \multirow{2}{*}{ Family size } & \multirow{2}{*}{ Total families } & \multicolumn{2}{|c|}{$\begin{array}{l}\text { Number of families having only } \\
\qquad F y(a+) \text { children }\end{array}$} \\
\hline & & Expected & Observed \\
\hline $\begin{array}{l}1 \\
2 \\
3 \\
4 \\
5 \\
8\end{array}$ & $\begin{array}{r}8 \\
23 \\
9 \\
2 \\
1 \\
1\end{array}$ & $\begin{array}{r}6.91 \\
17.54 \\
6.17 \\
1.26 \\
0.59 \\
0.51\end{array}$ & $\begin{array}{r}8 \\
18 \\
5 \\
1 \\
0 \\
0\end{array}$ \\
\hline Total & 44 & $32 \cdot 98$ & 32 \\
\hline
\end{tabular}

\section{Some children $\mathrm{Fy}(\mathrm{a}-)$}

The expected number of families with $F y(a-)$ children will be the difference between the total number of observed families of the type $F y(a+) \times F y(a+)$ and the expected number of such families whose children are all $F y(a+)$. In the present example the expected number of such families is $44-32 \cdot 98$ or I I 02 , while I 2 were observed.

A summary of the results of this method of family analysis is given in table 7 .

\section{METHOD 2}

In the families $F y(a+) \times F y(a+)$ with a child $F y(a-)$ it is possible to calculate the additional number of $F y(a-)$ children expected. 
Table $x$ shows that there are 12 such matings with $22 F y(a+)$ children and 5 additional $F y(a-)$ children (after the 12 diagnostic children have been excluded). The expected number of additional $F y(a-)$ children is simply $\frac{1}{4}(22+5)$ or $6 \cdot 75$.

\section{TABLE 7}

Analysis of certain of the families by method 2 (a)

\begin{tabular}{|c|c|c|c|c|c|}
\hline Class of mating & Class of family & $\begin{array}{l}\text { Expected } \\
\text { number of } \\
\text { families }\end{array}$ & $\begin{array}{c}\text { Obscrved } \\
\text { number of } \\
\text { families }\end{array}$ & $x^{2}$ & d.f. \\
\hline \multirow{4}{*}{$\begin{array}{l}F y(a+) \times F y(a+) \\
F y(a+) \times F y(a-)\end{array}$} & \multirow{4}{*}{$\begin{array}{l}\text { All children } F y(a+) \\
\text { Some children } F y(a-) \\
\text { All children } F y(a+) \\
\text { Some children } F y(a-)\end{array}$} & \multirow{4}{*}{$\begin{array}{l}32 \cdot 98 \\
11 \cdot 02 \\
22 \cdot 6 I \\
30 \cdot 39\end{array}$} & \multirow{4}{*}{$\begin{array}{l}32 \\
12 \\
18 \\
35\end{array}$} & \multirow{3}{*}{$\begin{array}{l}0.1167 \\
1 \cdot 6373\end{array}$} & \multirow[t]{3}{*}{ I } \\
\hline & & & & & \\
\hline & & & & & \\
\hline & & & & $\begin{array}{l}x \cdot 754^{\circ} \\
\text { bility }=\end{array}$ & 2 \\
\hline
\end{tabular}

Similarly there are 35 families $F y(a+) \times F y(a-)$ with a child $F y(a-)$. In these families there are 3 I $F y(a+)$ and 22 additional $F y(a-)$ children (again after the exclusion of the 35 diagnostic children). The expected number of additional $F y(a-)$ children is $\frac{1}{2}(3 \mathrm{I}+22)$ or $26 \cdot 50$.

The analysis by Method $2(b)$ is summarised in table 8 .

TABLE 8

Analysis by method 2 (b) of children from families containing $\mathrm{Fy}(\mathrm{a}-)$ children

\begin{tabular}{|c|c|c|c|c|c|}
\hline \multirow{2}{*}{ Matings } & \multicolumn{5}{|c|}{ Children } \\
\hline & & $F y(a+)$ & $\begin{array}{c}\text { Additional } \\
F y(a-)\end{array}$ & $\chi^{2}$ & d.f. \\
\hline \multirow{3}{*}{$\begin{array}{l}F_{y}(a+) \times F_{y}(a+) \\
F_{y}(a+) \times F_{y}(a-)\end{array}$} & \multirow{3}{*}{$\begin{array}{l}\text { Expected } \\
\text { Observed } \\
\text { Expected } \\
\text { Observed }\end{array}$} & \multirow{3}{*}{$\begin{array}{l}20 \cdot 25 \\
22 \\
26 \cdot 50 \\
31\end{array}$} & \multirow{3}{*}{$\begin{array}{l}6 \cdot 75 \\
5 \\
26 \cdot 50 \\
22\end{array}$} & & I \\
\hline & & & & $x \cdot 5283$ & I \\
\hline & & & & $\begin{array}{l}2 \cdot 133^{2} \\
\text { ility }=0\end{array}$ & 2 \\
\hline
\end{tabular}

The purpose of such analyses as those described in this paper is in the first place to disclose how a newly discovered blood group system is inherited. Conversely, once the manner of inheritance is established beyond doubt, good agreement between calculated and observed frequencies encourages confidence that the tests are being properly done. Furthermore, though the way of inheritance of a blood group system may be known with certainty, statistical analysis may reveal unexpected complications, such as for example, a differential survival rate. 


\section{SUMMARY}

The results are given of testing a further 325 unrelated English persons with anti-Fya . These bring the published number of such persons tested to 785 , of which $5^{1} 8$ or 65.99 per cent. were positive. This corresponds to the gene frequencies $F y^{a}=0.4 \mathrm{I} 68$ and $F y^{b}=0.583^{2}$.

The Duffy blood groups of a further 52 families are presented; these families together with $5^{8}$ previously reported from this Unit are submitted to statistical analysis. A method of analysis for the $A_{1} A_{2} B O$ groups, suggested by Fisher in 1939, is applied to the Duffy system. The family results are in good agreement with those expected on the assumption that the antigen $F y^{a}$ is controlled by a gene which expresses itself in single as well as in double dose.

Acknowledgments.-The authors have to thank Professor Fisher for any originality which this paper may contain.

For gifts of the serum anti-Fy $y^{a}$ we are indebted to Dr P. L. Mollison and Miss Marie Cutbush of the Medical Research Council Blood Transfusion Research Unit, to Dr P. Vogel and Dr R. E. Rosenfield of New York and to Dr J. J. van Loghem, Jr. of Amsterdam. For most of the other anti-sera used in the investigation we are indebted to Dr A. E. Mourant of the Medical Research Council Blood Group Reference Laboratory.

We are particularly grateful to the members of the families for their blood, and for their encouraging interest and cheerful tolerance of our intrusion.

\section{REFERENCES}

CUTBUSh, MARie, AND MOllison, P. L. I950. The Duffy blood group system. Heredity, 4, 383-389.

CUTBUSH, MARIE, MOLLISON, P. L., AND PARKIN, DOROTHY M. I950. A new human blood group. Nature, $165, \mathrm{I} 88$.

HOLT, HELENE A., THOMPSON, JOAN S., SANGER, RUTH, AND RACE, R. R. I 952. Linkage relations of the blood group genes of man : an analysis of 487 families with two or more children. Heredity, in the Press.

RACE, R. R., HOLT, HELENE A., AND THOMPSON, JOAN S. I95I. The inheritance and distribution of the Duffy blood groups. Heredity, 5, 103-1 Io.

RACE, R. R., IKIN, ELIZABETH W., TAYLOR, G. L., AND PRIOR, AILEEN M. I942. A second series of families examined in England for the $A_{1} A_{2} B O$ and $M \mathcal{N}$ blood group factors. Ann. Eugen., Lond., $I I, 385-394$.

RAGE, R. R., AND SANGER, RUTH. I950. Blood Groups in Man. Oxford : Blackwell Scientific Publications.

TAYLOR, G. L., AND PRIOR, AILEEN M. I939. Blood groups in England. III. Discussion of the family material. Ann. Eugen., Lond., 9, I8-44. 